\title{
The Consolidation of Local Resources and Sustainable Development in the Rural Space of Romania through Tradition and Tourism
}

\author{
Ionica SOARE ${ }^{\star}$
}

\begin{tabular}{l}
\hline \multicolumn{1}{c}{ A R T I C L E I N F O } \\
\hline Article history: \\
Accepted June 2019 \\
Available online August 2019 \\
\hline JEL Classification \\
L80, L83 \\
Keywords: \\
Local resources, Traditional \\
agrifood products, Tourist \\
resources, Entrepreneurs, \\
Intelligent villages, Traditional \\
occupations, Sustainable tourism
\end{tabular}

\section{Introduction}

The sustainable management of natural resources represents a priority of the implementation of the strategies focussed on rural space, because the quality of the environment is subject to pressure from the perspective of the natural process and of economic activities. That is why it is essential to promote sustainable practices in agriculture, tourism and other activities from rural space as well as to diversify the economic activities in ensuring the viability of the communities.

In Romania a great deal of the population is busy practising agriculture and gets income out of this activity. That is why, the facilitation of diversification, of financing and developing the small entreprises and creating workplaces is essential in rural areas with uneven relief, especially in disadvantaged mountainous areas, where due to the little areas of agricultural grounds, of the lack of agricultural mequipment and the access to loans, many agricultural exploitation are of subsistence.

At the same time, the strategies that are implemented highlight the encouragement of the projects which simultaneously integrate agriculture, rural tourism through promoting the sustainable tourism in rural areas, as well as the investments in sources of renewable energy. Through the diversification of the economic activities as a result of practising non -agricultural activities, the farmers and members of an agricultural household can receive financial support. Thus, the development of agricultural exploitation and nonagricultural enterprises aim at promoting the employment of workforce and creating quality jobs in rural areas, maintaining the already existing jobs.

The instruction and consultancy services will be playing a more and more important role in informing and training in agriculture and tourism as a result of the compulsory requirements regarding the environment and the climatic changes with impact on modernizing the farm, innovation ,competitiveness and entrepreneurship, thus creating the premisses of successfully applying the term " multifunctional development" and of developing the"cooperation patterns" for the tourist market. These aspects are possible because through its potential, the rural space of Romania can engender a series of activities differentiated from the local specific. 


\section{Materials and methods}

In approaching the phenomenon of consolidating the local resources and sustainable development in the rural space from Romania through tradition and tourism, we have taken into account the policy that Romania leads regarding the rural development. That is why the following aspects have been taken into consideration:

* the reflection of tradition along the lines of the patterns of nutrition in terms of the entrepreneurs of agrifood products (number and distribution) at the level of place, highlighting the local feature;

* selecting the administrative units (TAUs) in which are included the villages with traditional products from the list of disadvantaged areas (on TAUs) and the analysis of their situation in comparison with the total number of disadvantaged areas at the level of the country;

* the analysis of the distribution of tourist resources per TAU at the level of the country and the correlation between the score of the tourist resources on each county and the geographical distribution of entrepreneurs;

* The selection of tourist indicators for TAUs with entrepreneurship of traditional products and tourism;

The research has been made on the basis of the monitorization of the entrepreneurship from the agrifood sector with traditional products and from tourism through the survey from the National Register of the Traditional Products (NRTP) for the years 2014, 2015, 2016, 2017, 2018 and the statistic data on tourism on the site of The National Institute of Statistics of Romania.

\section{Results and discussions}

A series of aspects are deduced at the level of the rural space of Romania, as a result of the popularity that the rural tourism is gradually gaining, encouraged at governmental level as a remedy for the sustainable development of the communities and environment protection.

1) The identification of communities and spaces involved in the consolidation of local resources through traditional occupations and tourism

The elements of natural environment (relief, soil, climate) play a very important role, being a support in practising agriculture and developing the entrepreneurship of traditional products as well as tourism in general.

On the whole, by 2018 in Romania there has been constituted a network formed in Romania from 191 entrepreneurs with 607 certified traditional products disposed on 36 major administrative-territorial units ( 35 counties and the capital) from the total of 42 counties of the country, located in 38 towns and 118 villages ( $75 \%$ from the total number of municipalities).

Although throughout those four years there has been an increase in contrast with the year 2013, after the rigour of applying the Order no. 724 from 29th July 2013 regarding the certification of traditional products, the greatest number or rate was registered in the years 2014 and 2015, namely 150 entrepreneurs (78.53\% from the total number of entrepreneurs) with 499 traditional certified products $(82.20 \%$ from the total of traditional certified products). In the last two years - 2016 and 2017 there were only 31 entrepreneurs and 94 traditional products; the registered entrepreneurs were from counties that were found in RNTP for the years 2014-2015, but in other counties as well, generally from the exterior frame of the Carpathians and their contiguous areas (Iași, Neamț Vrancea, Caraș- Severin) except for Mureș county.

This registered situation corresponds to the period connected with the reorientation of the main actors' efforts at European and national level of supporting either a category of entrepreneurs or entrepreneurs from the same category through applying the piece of legislation (Decision no. 506 from July $20^{\text {th }} 2016$ ) regarding the labelling conditions for their products, the use of the term "mountainous product" in the case of products of animal origin, and also of financing and managing the National Register of mountainous products by the Ministry of Agriculture and Rural Development, as a competent authority.The same entrepreneur is not restricted to intervene on the market, besides traditional certified products and with certified products as " mountainous product" in the same way that the same producer / farmer can also have its products obtained in industrial system in the structure of their products.

The distribution of entrepreneurs and traditional agricultural products at the level of the counties and places within the same county highlights :

a) - a concentration of these generally in the mountainous and adjoining space ( where in fact the productivity is smaller than the one of the intensive agricultural space), emerged from the counties grouping ( 3 from those 4 groups took shape in the years 2014 an 2015):

a.1) - Braşov ( 31 entrepreneurs with 166 products in 19 places, first place in the country), Covasna ( 21 entrepreneurs with 25 products in 15 places) Argeș , Dâmbovița and Vâlcea ( 3 entrepreneurs with 12 products in 2 places), so a total of 69 entrepreneurs (36.12\% from the total of counties ) with 239 products ( 39.37 from the total) in 49 places ( $31.41 \%$ from the total);

a.2) - Alba , Hunedoara, Sibiu with 29 entrepreneurs with 75 products in 24 places; 
a.3) Maramureș (18 entrepreneurs with 65 products în 17 places) , Sălaj, Satu Mare (in the northwest of the country) totalizing 27 entrepreneurs with 104 products in 24 places;

a.4) Suceava, Neamț și Botoșani (in the north-east of the country) with 22 entrepreneurs with 69 products in 19 places, group taking shape on the back of the latest years studied.

b) - a reduced number or very small one of entrepreneurs and traditional certified products in the counties with the places disposed outside the Carpathians and the more fragmented relief units, except Tulcea county.

The categories of certified traditional products from NRTP reflect, besides the place / site through the patterns of nutrition and ethnic characteristic, traditional occupations, connected with agriculture and fishing: meat and meat products. milk and dairy products, vegetables fruit and drinks, panification and pastry products, fish.

The analysis of the insertion of this sort of entrepreneurship on TAU (parishes and towns) into each county which through the characteristics of the surfaces enter the category of disadvantaged areas ( DMA Disadvantaged Mountainous Area; SDA - Significantly Disadvantaged Area; ADSNC- Area Disadvantaged by the Specific Natural Conditions) indicates:

-87 entrepreneurs ( $45 \%$ compared with the total ) in the TAUs of the disadvantaged areas of 18 counties ( 10 counties only DMAs ) with about $50 \%$ certified products (306);

- a higher number of entrepreneurs at the level of each county in disadvantaged areas, especially from rural space, than from outside these, where there are TAUs registered in DMA;

- the number of traditional certified products of the entrepreneurs from the TAUs of disadvantaged areas (only with DMAs and with SDA) from the Carpathian and adjacent space is much higher than of those outside these, being twice or three times more, for example in the counties: Brasov- 120 products (72\% from the total county) in disadvantaged areas (110 in villages) and 46 outside these; Covasna - 17 products in disadvantaged areas ( only in villages) and 8 outside these.

It is worth mentioning that most of Romanian counties have a high number of TAUs in disadvantaged areas, from which 10 counties ( Alba, Maramureș, Bistrța- Năsăud, Covasna, Harghita, Hunedoara, Brașov, Tulcea, Constanța, Brăila ) each register around or over $50 \%$ (mainly parishes) from the total number of TAUs ( Harghita - about $90 \%$ ), most of them being in the Carpathian / mountainous and adjacent, precisely where there are the specified entrepreneurs / farmers and especially traditional products certified through a fairly high number.

However, following the names of the traditional products from NRTP there is no difference between the one obtained in disadvantaged area and the one outside the area. For instance: in DMA area " sheep cottage cheese Cățean Farm (132 number / NRTP 2014), Feldioara parish, Rotbav village, Brasov county, "whey cheese Cățean Farm" (134 number / NRTP 2014) and outside the disadvantaged "sheep pastrami" Neguț I. Gheorghe, Glicanul de Jos village, Rociu parish, Argeș county ( number of certificate 405 / NRTP 2015).

Generally, the development of a geographical space showcases tourist interest only to the extent in which the components of natural and anthropic environment through their qualitative and quantitative value show possibilities of capitalization, thus giving attract.

Thus, on the one hand,the correlation of the score of tourist resources ( natural and anthropic) for each county constituted through the addition of the score of all TAUs existing in disadvantaged areas of these on the basis of "The Plan of Organising the National Land " - the sixth section - tourist areas" Studies of substantiation, assessment of the tourist potential in administrative territorial units per county "and on the other hand the geographical disposition of entrepreneurs and of the products, leads to the following conclusions:

* the strong insertion of the entrepreneurship especially in the counties from the mountainous areas with high values of the score of tourist resources of over $40 \%$ ( reaching over $80 \%$ in Harghita, Alba, Maramureș, Covasna) seen as an advantage for success;

* signalling the diferences at the level of county that can be reached from the possibilities of capitalization both of the existing tourist potential and of that of traditional occupations through the entrepreneurs/ farmers;

* -the total average of the score of the tourist resources per TAU at the level of county bigger than 15 (over half of the maximum score of 25 points granted per TAU for one of those two categories of tourist resources) indicate important aspects in building a complex tourist profile of the disadvantaged areas within the corresponding county given by the variety of forms of tourism: tourism at the expense of the natural environment, cultural tourism, tourism related to traditional occupations (visits at the farms,etc), aco-agritourism, tourism based on cuisine and traditional products through organising festivals and fairs, etc;

* the natural component from the rural space, support in practising agriculture and developing the entrepreneurship on traditional products regularly constitute the factor of base attractiveness for tourism, thus registers the bigest values at the level of each county; the relief is the major element in the structure of natural potential, at the same time tinting the features of other elements of the natural 
environment, of climatic, hydrographic, biotic sort, causing the landscape value of the land of an area to increase.

It is worth mentioning that the evaluation of the potential has been done on the basis of "the Methodology regarding the evaluation of the tourist potential in basic administrative-territorial units."

Likewise, the analysis of the relationship resulted from the distribution of the villages with entrepreneurs on traditional products inside and outside disadvantaged areas and with indicators regarding the tourism for the years 2013 ( the year of the Order no. 724 from July 29th 2013 regarding traditional products)and 2017 supports an entrepreneurial network disposed in big established geographical areas- the area of Brașov Depression and Bran -Rucăr Corridor / Passage, of Maramureș, Apuseni Mountains and Bucovina -Neamț area - attracted not only by the tourist resources bu also welcoming structures with accommodation function. The same situation is also signalled in the "Study of Evaluation IV- Montainous Area " (version II, August 2018) which comprises the results of the observation activities, analysis and evaluation of the data regarding the interventions and actions financed between 2015-2017 through NRTP 2014-2020, at the level of mountainous area. It is highlighted the fact that there are theoretical possibilites for the small farms to find a niche strategy and the possibility to extend the distribution market, but this is valid only in certain tourist areas, such as Maramureș, the south of Transilvania, the Apuseni Mountains.

2) Opportunities of smart / intelligent vilages through the use of geographical characteristics in the territorial development and the concentration of human activities

a) Through "The National Plan of Rural Development" the business environment from rural space is stimulated by means of financial support for creating and developing activities, either agricultural or nonagricultural, for creating jobs, increasing the rural population's income and diminishing the differences between rural and urban.

The sub-measure " Investments in creating and developing nonagricultural activities, refers to the following categories of beneficiaries : farms which diversify their base activity through establishing or developing some non - agricultural activities ( focused on marketing the agrifood products, tourism) within already existing enterprise, incorporated in micro enterprises and little enterprises; micro enterprises and little enterprises existing in rural space.

Also, the sub-measure " The compensated payments in mountainous area" financially supports the use of agricultural lands because the disadvantaged mountainous areas are under the permanent threat of agricultural activities with production is affected by the climatical and relief conditions in TAUs situated at medium altitudes higher or equal with $600 \mathrm{~m}$ and at average altitudes between 400 and $600 \mathrm{~m}$ and which have an average slide equal or higher than $15 \%$; the limits of TAUs being those of physical blocks identified in the Integrated System of Administration and Control that belong to these TAUs. Through the characteristics of these TAUs, the position and variety of morphostructural forms of the villages are reflected starting from the area of high altitude of the Carpathians to the contact with the bordering units and highlight the authenticity of human settlements of Carpathian type and also the durability of their native stock.

In a study of the European Commission from 2013 the term "mountainous" according to EU Law corresponding to 'Less Favoured Areas (LFA) Mountain', as it is laid down in the CAP(Article 18.1 of Regulation (EC) 1257/1999: LFA Mountain) for the purpose of the financial compensation of natural handicap; is the criterion mentioned in the political proposals regarding the labelling of mountainous agricultural products.

According to the same study of the European Commission the mountainous areas appeared with $11.4 \%$ from the European agricultural production, Romania with 2.7 Mha was the fourth state member of EU in what concerns the mountainous agricultural surface after Spain (7.4 million hectars), Italy (4.3 Mha) și France (4.0 Mha). Because it is characterized by a large surface of LFA ('Less Favoured Areas) mountain "Agricultural labour (AWU- the workforce equivalent to one worker) per ha in mountain LFA areas vs. other areas" there are no important diferences in Romania (6.6 ha/ AWU LFA mountain and 6.1 ha/ AWU not LFA montain),as well as Greece (7.0 ha/ AWU LFA mountain și 7.2 ha/ AWU not LFA montain ) , Italy (10.3 ha/ AWU LFA mountain and 9.5 ha/ AWU not LFA mountain), Spain (27.5 ha/ AWU LFA mountain and 25.0 ha/ AWU not LFA mountain) , Slovenia (5.6 ha/ AWU LFA mountain and 6.2 ha/ AWU not LFA mountain, Slovakia ( $21.3 \mathrm{ha} /$ AWU LFA mountain and $21.2 \mathrm{ha} /$ AWU not LFA mountain).

b) The continuation of agricultural activity in mountainous areas on sustainable principles through grants holds an important role through the vertical transhumance, an agricultural practice (of breeding sheep and cows) regulated at European level, vulnerable but vital for landscapes. The Carpathian mountainous units at altitudes over $800 \mathrm{~m}$ dispose of a morphodynamic potential favourable to the processes fluvio - torential, crionival and gravitational that is why the anthropic pressure must be limited, has only seasonal status in case of grazing.

Practically it is about shoving sheep into the mountain sheepfold, with a duration that remained the same according to the ancient occupation disposed towards the end of May or the beginning of June, when the flock of sheep were going towards the sheepfold in the mountains" and after September 1 st when in general the descent and the breaking down of the sheepfolds was done in mountainous areas or around Octomber 1 
st depending on the weather. Many entrepreneurs obtain the certified traditional products, up in the mountains, during the moving of flocks.

Practicing the moving of the flocks is highlighted in the mountainous space through:

* cookery festivals (e.g. Sheep's scattering - The Festival of the cheese and pastrami" from Bran, Brașov county, from the last end of the week in September, held on the Queen's Plateau"), whose date is generally correlated with the traditional occupation and nature cycles, the traditional occupation being promoted as well, but also a traditional product or a category of products from local and regioal cuisine, that is a part of the cultural heritage of the host local community or of the region in which the place of unfolding the event is framed. These constitute a form of advanced connection with tourism to generate business activities and income for the host communities.

* The existence of the villages with the same name as the entrepreneurs for traditional products from counties such as: Brasov, Arges, Dâmbovița with the ones found in historical documents, for example for the peak period of the reduced moving of the flocks are registered as belonging to a Transilvanian household from Bran region (Vlădeni, Bran, Șirnea, Fundata, Șimon, Moeciu) from Brasov district (Prejmer), are specified villages such as Bran, Moieciu, Fundata that appealed to wide moving of flocks ( with the shoving on the southern and eastern mountainsides of the Carpathians, in the Romanian Country and Moldova) and villages on the way of the moving of the flocks from the Romanian Country, some of them formed of Romanian Transilvanian, such as Jgeaburi from Argeș county.

c) From the data bases of the National Institute of Statistics Bucharest regarding the accommodation units and the capacity of accommodation in operation - it is evident that the villages from the counties with entrepreneurship have formed and developed their own fund of the tourist welcoming and services, the towns being prior to the situation of lift-off ramp of the tourist flow inserted through infrastructure.

The tourist accommodation capability in function (number of places - days) of the villages in 2017 in comparison with 2013 registers increases for almost all the counties, the biggest being in Brașov county( over 1 million), Sibiu( almost 500), Harghita and Neamț ( with almost 400 each); the values of about and over 50 $\%$ for both years (2013 and 2017) reflect the competition installed between rural and urban and the development of rural tourism for the counties such as Alba, Bihor, Buzău, Dambovița and Neamț.

The high values of tourist indicators in 2017 in comparison with 2013 in the villages that also have entepreneurs and the tourist activity is ascribed, among others to the contribution of entrepreneurship at tourist package. The extension of the duration of tourists' stay or/ and the increase of tourist flow is always reflected in visitors' / tourists' taking the decision of buying local agrifood products, in increasing the amount of money spent both on these products and on other tourist activities during the remained stay.

"UNWTO Report on Gastronomy Tourism: sustainability and gastronomy" from 2017, presented in the third world forum UNWTO from Spain, regarding cuisine and cookery tourism, highlights the idea that cuisine has become a major motivation to visit a destination and that cookery tourism provides an enormous potential of stimulating the local, regional and national economies and of enhancing the sustainability and inclusion.Brasov county already signals this situation.

Only through the villages of Brașov county, belonging to disadvantaged area such as Șirnea (11.6 rate products / entreprenour), Bran (7.25 rate products / entreprenours), Fundata ( 5.75 rate products / entreprenours) it is already shown the high level reached by the entrepreneurs of a village, so that one entrepreneur, only through its own products or through supplementing from the others, can fully sustain the tourist activity for festive / ceremonial meals (Christmas, Easter) which best reflects the power of influence of tradition, not to mention the habitual / usual meals or the snacks prepared from fresh farm products as a result of a visit on a farm. Agribusiness is becoming efficent only to the extent in which consumers are provided with groceries in sufficient quantities in a corresponding variety and at reasonable prices.

The size and distribution of the tourist potential and the degree of capitalization at spacio-temporal level through certain tourist indicators as well as the size and distribution of the entrepreneurial network confer aspects that can anticipate situations connected with the impact, oriented either towards developing the land or towards signalling a risk. For example: the identification of existing and potential tourist attractions from rural areas capable of offering solutions to be introduced in certain rural settlements in order to make them more appealing for tourists; the tourist pressure in the context of sustainable development.

The subject was an approach as an answer to the major directions of the term territorial cohesion political goal at European level, which draws attention on knowing the land for signalling and acknowledging its diversity with the need to build in order to generate the socio-economic development.

\section{Conclusions}

* the insufficient capitalization of geographical characteristics in territorial development of the adjacent mountainous space compared with the potential provided by this;

* outlining a network of communities from mountainous and adjacent space which through innovational solutions on the lines of the sector of agrifood products and tourism, seek to improve the resistence and 
to consolidate the local resources in order to benefit from opportunities in developing their places and to become examples regarding applying the term of intelligent village;

* the gradual farmers' awareness of the positive effects of the diversification of their activity, of also being creative when it comes to non-agricultural activities, and which focuses the activities on providing some mass-consumed products for the time being;

* the stimulation of the cooperation for creating networks and chains of supply with a view to overcoming the difficulties caused by the fragmentation and with a view to creating new opportunities on the market;

* a more difficult achievement in disadvantaged mountainous areas of promoting the integration of food chain within the support measures through the development programme of the rural space;

* wide possibilities of development for sustainable tourism in mountainous and adjacent area at the expense of traditional occupations and capitalization of tourist potential;

\# the emphasis of encouraging communities to explore new ways through which to become or remain competitive, to fully capitalize the goods and overcome the difficulties they might encounter.

\section{References}

1. Temirbulatova Madina, Borza Mioara (2015) THE MODEL OF BUSINESS RESEARCH OF AGRITOURISM POTENTIAL IN RURAL AREAS OF DEVELOPING COUNTRIES, SYNTHESIS 2015 - Tourism and hospitality, International Scientific Conference of IT and BusinessRelated Research, http://portal.sinteza.singidunum.ac.rs/Media/files/2015/486-490.pdf

2. Borodako Krzysztof, Kožić Ivan (2016), COOPERATION PATTERNS IN THE TOURISM BUSINESS: THE CASE OF POLAND, Prague Economic Papers, 25(2), 160-174

3. http://www.dajsj.ro/doc/0742-00215/ordin-privind-atestarea-produselor-tradi_ionale.pdf

4. The Ministry of Agriculture and Rural Development; http://www.madr.ro/docs/ind-alimentara/hot-506-din-20-iulie-2016-produsmontan.pdf

5. The Ministry of Agriculture and Rural Development, The National Programme of Rural Development 2007 - 2013, reinforced version November 2013; http://www.madr.ro/docs/dezvoltare-rurala/PNDR_2007-2013_versiunea-consolidata-nov2013.pdf; pp 767-797

6. http://www.mdrl.ro/_documente/dezvoltare_teritoriala/amenajarea_teritoriului/patn_elaborate/secVI/judete/vaslui/sinteza.pdf

7. http://www.mdrl.ro/_documente/dezvoltare_teritoriala/amenajarea_teritoriului/patn_elaborate/secVI/metodologie.pdf

8. http://www.dajsj.ro/doc/020215/ordin-privind-atestarea-produselor-tradi_ionale.pdf

9. Cucu Vasile, Geografia așezărilor rurale, Domino Publishing House, Târgoviste, 2000, pp 104-105

10. Santini Fabien, Guri Fatmir, Gomez y Paloma Sergio, Labelling of agricultural and food products of mountain farming, European Commission, Luxembourg: Publications Office of the European Union, 2013, p.22;

11. http://www.arepoquality.eu/sites/arepoquality.eu/files/press/Study.pdf

12. Santini Fabien, Guri Fatmir, Gomez y Paloma Sergio, Labelling of agricultural and food products of mountain farming, European Commission, Luxembourg: Publications Office of the European Union, 2013, p.26;

13. http://www.arepoquality.eu/sites/arepoquality.eu/files/press/Study.pdf

14. Ielenicz Mihai, Pătru Ileana, Geografia fizică a României, Universitară Publishing House, București, 2005, p 189

15. Allen Johnny, O'Toole William, Harris Robert, McDonnell Ian, Festival \& special event management, fourth edition, Willey, Austral, 2008, pp. $15-16$

16. Iordache Gheorghe, Ocupații tradiționale pe teritoriul României - ethnological study, vol II, "Scrisul Românesc", Publishing House, Craiova, 1986, pp.18, 29

17. Institutul Național de Statistică București, http://www.insse.ro/cms/ro/content/indicatori-de-statistica-regionala-tempo; accesed on 5th November 2018

18. SKURAS D., DIMARA E. and PETROU A (2006) Rural tourism and visitors' expenditures for local food products, Regional Studies 40, 769-779, http://www.tandfonline.com/doi/abs/10.1080/00343400600660771

19. UNWTO Report on Gastronomy Tourism: sustainability and gastronomy, World Tourim Organization, http://media.unwto.org/pressrelease/2017-05-17/2nd-unwto-report-gastronomy-tourism-sustainability-and-gastronomy

20. The Ministry of Agriculture and Rural Development, The National Register of Traditional Products,

21. http://data.gov.ro/dataset/registrul-national-al-produselor-traditionale/resource/5cf69c59-1029-466e-9de2-e8626633e0b4( accesare 05. 05. 2018)

22. Carwford, I.M, Agricultural and Food Marketing Management, Editura FAO, Roma, 1997

23. https://www.fonduri-structurale.ro/Document_Files/Stiri/00017493/7hctm_Anexe.pdf 